\title{
Genetic Traceability of Cinta Senese Pig (Sus scrofa domesticus L.): A Study of the Meat and Processed Products by Microsatellite Markers
}

\author{
Monica Scali' ${ }^{1}$ Rita Vignani ${ }^{2}$, Marco Quintetti' ${ }^{1}$ Jacopo Bigliazzi1 ${ }^{1}$, Elisa Paolucci², \\ Mauro Cresti ${ }^{1}$ \\ ${ }^{1}$ Department of Life Science, University of Siena, Siena, Italy \\ ${ }^{2}$ Serge-Genomics S.r.L., Siena, Italy \\ Email: monica.scali@unisi.it
}

Received 9 January 2015; accepted 21 May 2015; published 26 May 2015

Copyright (C) 2015 by authors and Scientific Research Publishing Inc.

This work is licensed under the Creative Commons Attribution International License (CC BY).

http://creativecommons.org/licenses/by/4.0/

(c) (i) Open Access

\begin{abstract}
Traceability based on DNA analysis is attracting increasing interest due to the crisis of confidence that consumers show towards the products of animal origin. The present work discusses a genetic traceability system of meat and processed products from an historical Tuscan native pig breed, the Cinta Senese. The study is based on a panel of 8 ISAG (International Society for Animal Genetics) DNA microsatellite markers usage done both on pigs and derived products. The SSRs panel allowed us to obtain a unique fingerprint of the individuals to be used as a tracer "downstream" in the processed products. The molecular method used proved that the hams, analyzed just before commercialization, were obtained from Cinta Senese pigs and that the analyzed meat products derived from the Cinta Senese were produced at least with $95 \%$ of Cinta Senese meat. In perspective, the molecular testing could be introduced as a voluntarily adopted method for proving intrinsic quality of many regional food products.
\end{abstract}

Keywords

Sus scrofa domesticus L., Genotyping, SSRs, Meat Molecular Traceability

\section{Introduction}

The Cinta (meaning belt) Senese (of Siena)—(CS) is an autochthonous pig (Sus scrofa domesticus L.) breed

How to cite this paper: Scali, M., Vignani, R., Quintetti, M., Bigliazzi, J., Paolucci, E. and Cresti, M. (2015) Genetic Traceability of Cinta Senese Pig (Sus scrofa domesticus L.): A Study of the Meat and Processed Products by Microsatellite Markers. Food and Nutrition Sciences, 6, 712-726. http://dx.doi.org/10.4236/fns.2015.68074 
widespread in Tuscany, that had almost been lost during the '60s. Originating in Tuscany from around the areas of Siena, it is believed that this ancient hardy breed is more than likely bred in Roman times, although the earliest acknowledgements found are dating from the Middle Ages. Within Siena's Town Hall, an historical image of the CS can be found in painting entitled "Effects of Good Government in the Country" by artist Ambrogio Lorenzetti (1338). Free-range pig farming is of great significance, both for animal health and for lowimpacting farming to the environment. Up and into the 1950's many people owned one or more CS for their meat, but a period of decline of the CS was attributed to a massive cross breeding with white pig breeds, which needed to be kept for a much shorter period than the CS before butchering. Among those, Large White (LW), that was introduced to Italy from the UK and Landrace (L) that was introduced mainly from several Scandinavian Countries.

However, the white breeds could not adapt to the same wild or semi-wild farming and terrain that the CS was so familiar with. This led to a successful crossbreeding between the CS and the white breeds that allowed avoiding extinction of the CS breed due to an excessive inbreeding. On the other hand, the interbreeding crossings arouse doubts concerning the genetic identity of the original CS breed.

In the year 2000, a voluntary Consortium was established in Siena, today known as "Consorzio di Tutela della Cinta Senese" (Consortium for the Defence of Cinta Senese). Products are given a tag confirming their origin, that is, a Protected Designation of Origin (PDO), which means the animal from which the produce is derived was born raised and slaughtered in Tuscany.

Several CS products (Salami, lard, pancetta, bacon and other cured meats, sausages, capocollo, and shoulder) can be purchased from delicatessens within Tuscany's provinces of Siena, Grosseto and Florence and that can be considered a typical Italian Regional food that characterizes the Mediterranean diet. The authentic products will have a label "Cinta Senese D.O.P" attached, but at the moment no molecular testing has been associated to this label with the exception of research studies, including the present. The CS meat is rich of high quality nutraceuticals, such as a favorable unsaturated/saturated fatty acids ratio, a high content in branched amminoacids and a quite low atherogenic and thrombogenic indexes [1].

The rediscovery of the CS pig is due mainly to the increasing demand for typical Italian Regional quality food by consumers. These pigs are characterized, in fact, for rich and tasty meat, whose characteristics are appreciated for processing into traditional salami.

Traceability of food products has become an important field of study for proving the intrinsic quality of typical food and is fundamental to ensure that consumers are supplied with genuine products. DNA testing of food proves its composition and maintains a high level of consumer confidence in relation to food quality and safety [2] [3].

There are several analytical methods available to the scientific community to assess the composition and geographical origin of the main ingredients of food. Many different techniques have been increasingly introduced in the framework of documental traceability programmes in compliance with National and International regulations, or by producers that voluntarily wish to ensure their products have an extra guarantee of quality.

Traditionally, the species or variety identification of food ingredients can be performed through the chemical analysis of proteins or secondary metabolites with NIR spectroscopy or mass spectrometry. Chemical-based methods are currently also used to obtain information on the safety requirements in regard to undesired chemical molecules, such as pesticides or other synthesis molecules that may have been used during growth or storage of the ingredients ([4] [5]) or for studying the nutraceutical content [6]. Examples of such studies have recently improved the content of international publications databases and include different case studies concerning different food categories. Among others, there are studies on livestock products and meat [7]-[9], wine and spirits [10]-[13], several plant species like cocoa beans, chicory, wheat and garlic [14]-[18], olive oil [19]-[26], on eggs [27].

The presence of DNA traces in different food matrixes, together with the extraordinary chemical stability of this molecule, renders DNA an ideal candidate for tracing the composition and origin of food. Molecular traceability is nowadays becoming a common methodology for different areas of food industry.

Molecular traceability methods have been boosted by GMO traceability law requirements, especially in European Countries where GMO planting and use is strictly regulated by law or even forbidden in particular food categories, like food for babies [28]. Examples of GMO tracking that concerns the food industry include corn [29], and soybean [30].

DNA tracing is used for proving the genuinity of milk and cheese products [31], meat [32]-[37], fish- 
containing derivatives [38] [39], olives [40], olive oil [41]-[47], and others [48]. The detection and reading of DNA residues, even in conditions of highly degraded traces of DNA, is made possible through the use of a classical molecular technique, the Polymerase Chain Reaction (PCR) both in the classical and more recent version, the Real-Time PCR (RT-PCR). While the classical PCR provides a qualitative assay, the RT-PCR, which is commonly used also in medicine as a diagnostic tool, can estimate the quantity of DNA initially present in a sample. Both could be considered the key techniques for nucleic acid amplification. PCR is in fact also widely used in forensic science for the genotyping of LCN (Low Copy Number) DNA traces found in crime or disaster scenes [49].

Thanks to next-generation sequencing technologies, there is a wide range of choice of DNA molecular markers that are currently available to the scientific community for different focused studies, such as genetic population analysis, for monitoring genetic identity and variability in a natural population, for parentage testing or for tracing meat through the entire food chain.

SNPs markers are considered the newest type of molecular markers that are supposed to offer great opportunities in mammals since they are abundant in the genome, are genetically stable and can be detected in a high throughput system [50]. Unfortunately, allele frequencies for SNP markers in Cinta Senese pig populations are not available and their use for Cinta Senese authentication has never been explored.

The most commonly used molecular markers for genetic identification and traceability in forensic and animal/crop sciences are the SSRs or microsatellite [51]-[53]. These molecular markers are highly polymorphic, informative and interspersed throughout the entire genome and for their characteristics have been proposed for tracking food, including meat and wine [54].

Recent works showed as SSR markers are suitable for distinguish genotypically the Cinta Senese breed from the main white breeds spread in Italy and that the use of a general, neutral SSRs genotyping approach, seems appropriate in determining the pig breed identity [53]. Therefore, the aim of this work was to verify the utility of the SSR markers for the implementation of a molecular traceability system through the whole Cinta Senese production chain, from meat to processed products.

\section{Materials and Methods}

\subsection{Sampling and Genomic DNA Extraction}

The meats coming from six different CS pigs post-mortem were numbered consecutively (from CSmeat1 or CScarne1 to CSmeat6 or CScarne6) and used for the extraction of genomic DNA by the GenElute Mammalian Genomic DNA Kit (Sigma-Aldrich, MO, USA). All the samples were analyzed in triplicate.

The same commercial kit was used for the extraction of genomic DNA from two CS salami, each analyzed in triplicate. In particular, $250 \mathrm{mg}$ of salami meat, including fat, were homogenized using the Tissue Lyser Disruption System (Qiagen) and $25 \mathrm{mg}$ of the homegenized meat were used for DNA extraction.

Likewise, the GenElute Mammalian Genomic DNA Kit was used to extract genomic DNA from each of the following samples always analyzed in triplicate: fresh CS ham belonging to a butchery batch that included, among others, the six individuals used for the meat analysis (Ham1 or Prosciutto1); pigskin coming from the same fresh CS ham (Pigskin1 or Cotenna1); aged CS ham not belonging to the butchery batch of the six individuals used for the meat analysis (Ham2 or Prosciutto2).

All the DNAs were analyzed on agarose gel and quantified by biophotometer (Eppendorf) using the ratio 260/280 nm to assess the purity of DNA and the ratio 260/230 to exclude the presence of contaminants which absorb at $230 \mathrm{~nm}$. The amount of DNA extracted from all kinds of simples varies from 15 to $25 \mu \mathrm{g}$.

\subsection{SSRs Genotyping}

The genomic DNA of all samples (meats, salami and hams) were amplified at 8 SSRs loci (S0026, SW240, S0068, SW122, SW632, SW1828, SW1067, S0226) (Table 1) recommended by ISAG/FAO and selected as most suitable for genetic identification of CS breed according to polymorphic information and allele frequency reported by [53].

All PCR reactions were carried out in an Eppendorf Mastercycler Gradient PCR in a total volume of $12.5 \mu 1$, containing $10 \mathrm{ng}$ of genomic DNA, $0.25 \mathrm{mM}$ dNTPs (Promega), $0.25 \mu \mathrm{M}$ each primer (one of them being fluorescein labeled), 1X Green GoTaq ${ }^{\circledR}$ Reaction Buffer containing $1.5 \mathrm{mM} \mathrm{MgCl}_{2}$ (Promega), $0.1 \mathrm{U}$ Go Taq ${ }^{\circledR}$ 
Table 1. Microsatellite primer sequences.

\begin{tabular}{ccc}
\hline Locus & Forward Primer & Reverse Primer \\
S0026 & AACCTTCCCTTCCCAATCAC & CACAGACTGCTTTTTACTCC \\
SW240 & AGAAATTAGTGCCTCAAATTGG & AAACCATTAAGTCCCTAGCAAA \\
S0068 & AGTGGTCTCTCTCCCTCTTGCT & CCTTCAACCTTTGAGCAAGAAC \\
SW122 & TTGTCTTTTTATTTTGCTTTTGG & CAAAAAAGGCAAAAGATTGACA \\
SW632 & TGGGTTGAAAGATTTCCCAA & GGAGTCAGTACTTTGGCTTGA \\
SW1828 & AATGCATTGTCTTCATTCAACC & TTAACCGGGGGCACTTGTG \\
SW1067 & TGCTGGCCAGTGACTCTG & CCGGGGGATTAAACAAAAAG \\
S0226 & GGTTAAACTTTTNCCCCAATACA & GCACTTTTAACTTTCATGATGCTCC \\
\hline
\end{tabular}

DNA Polymerase (Promega). PCR conditions included an initial denaturation step of $5^{\prime}$ at $95^{\circ} \mathrm{C}, 39$ cycles of $30^{\prime}$ at $95^{\circ} \mathrm{C}, 30^{\prime}$ at $55^{\circ} \mathrm{C}, 1^{\prime}$ at $72^{\circ} \mathrm{C}$ and a final extension of $10^{\prime}$ at $72^{\circ} \mathrm{C}$.

The PCR products were separated on $2 \%$ agarose gel stained with ethidium bromide to identify possible imperfections and to decrease the rate of failure in capillary electrophoresis.

$2 \mu \mathrm{l}$ of PCR product and $12.5 \mu \mathrm{l}$ of an internal size standards (Et-Rox-400, GE) were denatured at $95^{\circ} \mathrm{C}$ for 2' and kept on ice. The allele sizing was done by capillary electrophoresis, based on laser scanning of fluorescence-marked DNA fragments. Genotyping was done on MegaBACE 500 DNA Analysis System and evaluated by software Fragment Profiler version 1.2 (GE Healthcare, USA). In Figure 1 two typical electropherogram images are shown.

\subsection{Dendogram of Similarity}

The similarity dendograms have been obtained using NTSyS 2.1 software, the clustering algorithm is SAHN and among the different options, UPGMA was selected as hierarchical method for the tree construction.

\section{Results}

\subsection{CS Meat Genotyping}

The present study focused to the development of a genetic traceability plan along the CS supply chain, from meat to the processed products. The tracking is based on the comparison between the DNA profiles of six CS meat samples, coming from different CS individuals, with the DNA profiles obtained from the processed products. The SSRs markers are frequently used in breeding program for their discrimination power. The effectiveness of a SSRs panel is usually tested by the probability of identity (PI) that is the probability of finding, by chance, two individuals with the same profile. Therefore, to ensure that each individual is univocally characterized it is essential to use a set of sufficiently polymorphic loci.

The meats coming from six different CS pigs post-mortem were genotyped at 8 SSRs loci (S0026, SW240, S0068, SW122, SW632, SW1828, SW1067, S0226) [53]. The allele sizes characterizing the genotype of each CS pig post-mortem were used for the production of a dendrogram of similarity by NTSYS 2.0, including the different pig breeds belonging to our private databank listed in Table 2 [53].

The analysis of the dendrogram of similarity reveals that the six CS meat samples share the "consensus genotype" typical of the CS pig breed and differ from other breeds and crossbreeds included as controls (Figure 2), verifying their belonging to CS breed.

\subsection{Sensitivity Test of White Pig Meat in Blended CS-White Pig Meat Samples}

For this aim, two white pig meat samples (White pig meat 1 and White pig meat 2), coming from two different white pigs (post-mortem) which had no relationship with the CS breed, were genotyped at the 8 SSRs loci previously listed and the allele sizes were compared with the allele sizes of the six CS meat samples above described (data not shown). The comparison reveals that the CS meat 1 shows the highest number of discriminating alleles respect to the two white meat samples (Table 3) and therefore it was identified as the most suitable to 

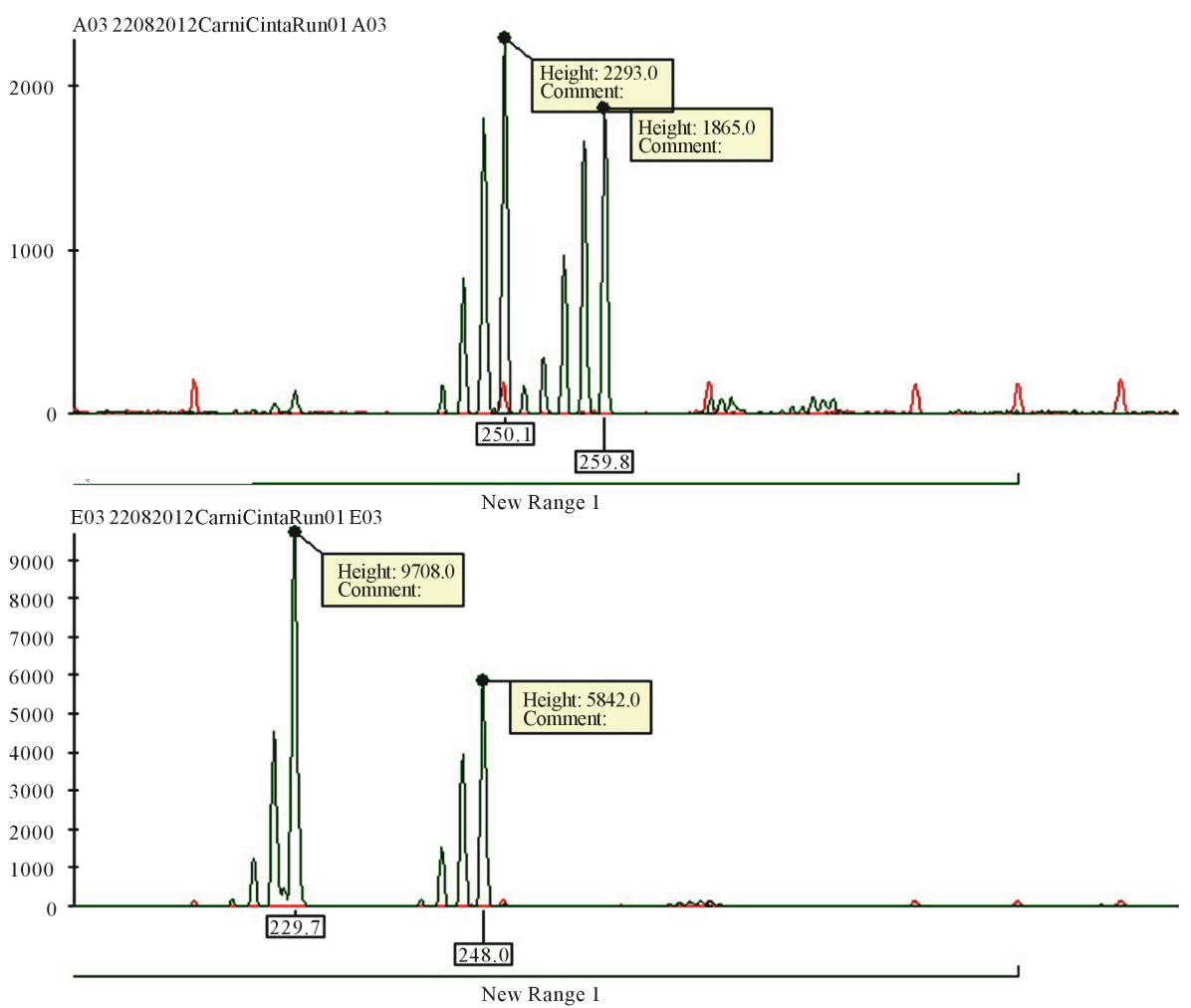

(a)
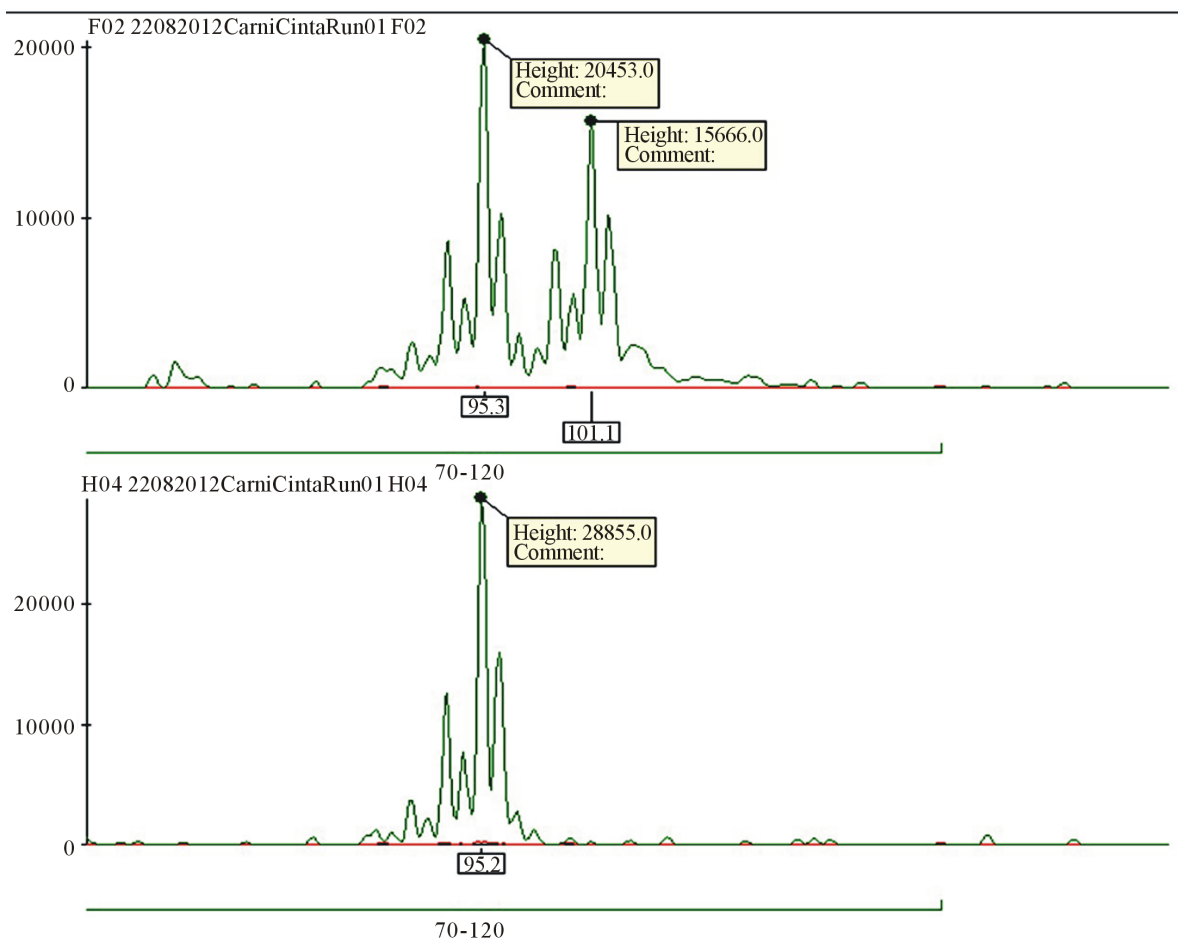

(b)

Figure 1. Typical electropherogram images. CS meat DNA amplification at S0068 locus (upper line, (a)) compared to the white pig meat profile (lower line, (a)). White pig meat DNA amplified at S0026 locus (upper line, (b)) compared to the CS meat profile (lower line, (b)). 
Table 2. List of pig breeds analyzed.

\begin{tabular}{|c|c|}
\hline Breed & Reference number \\
\hline \multirow{13}{*}{ Cinta Senese } & $25 \mathrm{~A}$ \\
\hline & $20 \mathrm{~A}$ \\
\hline & $19 \mathrm{~A}$ \\
\hline & $29 \mathrm{~A}$ \\
\hline & $14 \mathrm{~A}$ \\
\hline & $53 \mathrm{~A}$ \\
\hline & $54 \mathrm{~A}$ \\
\hline & $16 \mathrm{~A}$ \\
\hline & $27 \mathrm{~A}$ \\
\hline & $55 \mathrm{~A}$ \\
\hline & $28 \mathrm{~A}$ \\
\hline & $31 \mathrm{~A}$ \\
\hline & $18 \mathrm{~A}$ \\
\hline \multirow{5}{*}{ Landrace } & 1 \\
\hline & 2 \\
\hline & 3 \\
\hline & 4 \\
\hline & 5 \\
\hline \multirow{4}{*}{ Large White } & 6 \\
\hline & 7 \\
\hline & 8 \\
\hline & 9 \\
\hline \multirow[t]{2}{*}{ Large White $\times$ Landrace } & 10 \\
\hline & 11 \\
\hline \multirow[t]{5}{*}{ Landrace $\times$ Cinta Senese } & 12 \\
\hline & Duroc1 \\
\hline & Duroc2 \\
\hline & Duroc3 \\
\hline & Duroc4 \\
\hline \multirow[t]{8}{*}{ Duroc } & Duroc5 \\
\hline & Duroc6 \\
\hline & Duroc7 \\
\hline & Duroc8 \\
\hline & Duroc9 \\
\hline & Hampshire1 \\
\hline & Hampshire2 \\
\hline & Hampshire3 \\
\hline \multirow[t]{4}{*}{ Hampshire } & Hampshire4 \\
\hline & Hampshire5 \\
\hline & Hampshire6 \\
\hline & Hampshire7 \\
\hline
\end{tabular}

produce blended samples (CS-White pig meat samples) to be analysed for the lower limit of detection of white meat.

Table 3 shows the White pig meat 1 and 2, for this set of samples, have discriminating alleles in 7 out of 8 loci. In particular, 4 SSRs loci (S0026, S0068, SW1067, S0226) have alleles that differ by more than 7 bases and therefore more easily identifiable. 


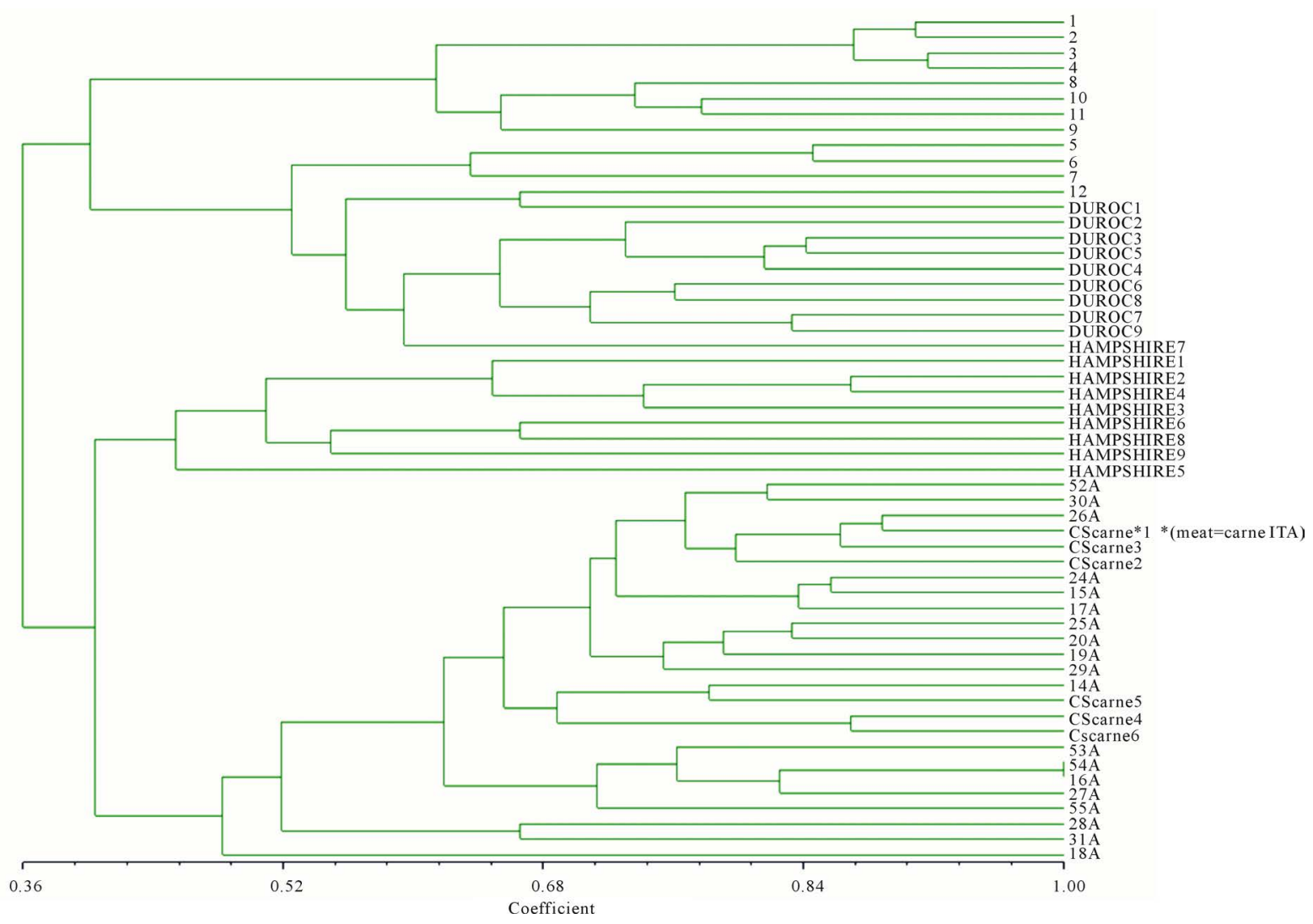

Figure 2. Dendrogram of genetic similarity obtained by the "unweighted pair-group method with arithmetic mean (UPGMA).” The six CS meat samples (from Cscarne 1 to Cscarne 6) analyzed show a genotypic profile corresponding to the Cinta Senese breed, differing from other pig breeds listed in Table 2.

Table 3. Meat genotyping. Comparison of the allele sizes of the White pig meat 1 and 2 and the CS meat 1 . The discriminant alleles shown in bold in the last right column, are univocally associated with the meat coming from the 2 different white pigs analyzed.

\begin{tabular}{|c|c|c|c|c|}
\hline & White pig meat 1 & White pig meat 2 & CS meat 1 & Discriminant alleles \\
\hline S0026a & 102 & 95 & 95 & \\
\hline S0026b & 102 & 95 & 95 & 102 \\
\hline SW240a & 97 & 97 & 97 & \\
\hline SW240b & 97 & 97 & 108 & \\
\hline S0068a & 230 & 230 & 250 & \\
\hline S0068b & 256 & 250 & 260 & $230 / 256$ \\
\hline SW122a & 114 & 125 & 121 & \\
\hline SW122b & 118 & 125 & 130 & $114 / 118 / 125$ \\
\hline SW632a & 160 & 162 & 162 & \\
\hline SW632b & 173 & 162 & 169 & $160 / 173$ \\
\hline SW1828a & 94 & 94 & 96 & \\
\hline SW1828b & 98 & 98 & 100 & 94/98 \\
\hline SW1067a & 160 & 160 & 168 & \\
\hline SW1067b & 160 & 170 & 170 & 160 \\
\hline S0226a & 180 & 192 & 178 & \\
\hline S0226b & 198 & 198 & 178 & $180 / 192 / 198$ \\
\hline
\end{tabular}


Therefore, White pig meat 1 and White pig meat 2 were mixed separately with the CS meat 1 according to the percentages shown in Table 4 and the blended samples obtained were genotyped at the 4 SSRs loci above mentioned in order to establish the lower limit detection of the white pig meat.

The analyses reveals that the alleles of the white meat are not detectable in cuts under than $5 \%$, both in the blended produced with the White pig meat 1 that in the blended produced with the White pig meat 2 (Table 5). The lower limit of detection up to $5 \%$ recorded in this study refers to an analysis carried out by qualitative PCR.

\subsection{CS Salami Genotyping}

Two CS salami were genotyped at the 8 SSRs loci used for the six CS meat samples. By comparing the results of the salami analysis with those deriving from the analysis of CS meat, it was possible to highlight a perfect match of the allele sizes in all loci analyzed with the exception of the locus S0068 that in addition to alleles 230, 250 and 260 shows, in both salami, a 240 bp allele (Table 6). Comparing this result with our private databank it has been shown that the 240 bp allele is recurring for the S0068 locus in the CS breed genotype and does not occur in crossbreeds (Landrace $\times$ Large White and Landrace $\times$ Cinta Senese) [53] and in the other pig breeds genotyped (Landrace, Large White, Duroc and Hampshire). The results allow us to affirm that the two salami analyzed were probably produced using not only the meat coming from the six CS pig genotyped in this project, but also meat coming from other CS pigs belonging to the same butchery batch of the six CS pigs used for the meat

Table 4. Sensitivity test of White pig meat in blended CS-White pig meat samples.

\begin{tabular}{|c|c|c|}
\hline Sample number & CS meat 1 & White pig meat 1 \\
\hline 1 & $99 \%$ & $1 \%$ \\
\hline 2 & $97.5 \%$ & $2.5 \%$ \\
\hline 3 & $95 \%$ & $5 \%$ \\
\hline 4 & $90 \%$ & $10 \%$ \\
\hline 5 & $85 \%$ & $15 \%$ \\
\hline 6 & $80 \%$ & $20 \%$ \\
\hline 7 & $75 \%$ & $25 \%$ \\
\hline 8 & $70 \%$ & $30 \%$ \\
\hline 9 & $65 \%$ & $35 \%$ \\
\hline 10 & $60 \%$ & $40 \%$ \\
\hline 11 & $55 \%$ & $45 \%$ \\
\hline 12 & $50 \%$ & $50 \%$ \\
\hline Sample number & CS meat 1 & White pig meat 2 \\
\hline 13 & $99 \%$ & $1 \%$ \\
\hline 14 & $97.5 \%$ & $2.5 \%$ \\
\hline 15 & $95 \%$ & $5 \%$ \\
\hline 16 & $90 \%$ & $10 \%$ \\
\hline 17 & $85 \%$ & $15 \%$ \\
\hline 18 & $80 \%$ & $20 \%$ \\
\hline 19 & $75 \%$ & $25 \%$ \\
\hline 20 & $70 \%$ & $30 \%$ \\
\hline 21 & $65 \%$ & $35 \%$ \\
\hline 22 & $60 \%$ & $40 \%$ \\
\hline 23 & $55 \%$ & $45 \%$ \\
\hline 24 & $50 \%$ & $50 \%$ \\
\hline
\end{tabular}


Table 5. Lower limit detection of White pig meat in blended CS-White pig meat samples. The allele sizes in bold are the white meat alleles identified in the blended meat analyzed. The alleles of the white meat are not detectable in cuts under than $5 \%$. In the CS-White1 pig meat samples, at the S0068 locus (see * in Table 5a), the allele 256 tyipical of the white meat in this study, hasn't picked out, probably due to the "allele drop out" (PCR loss of one allele) phenomenon which generally occurs when the quantity of DNA is relatively low, either because the sample is limited or because the DNA it contains is degraded, and hence the test is near its threshold of sensitivity.

\begin{tabular}{|c|c|c|c|c|c|c|c|c|c|c|c|c|}
\hline \multicolumn{13}{|c|}{ a-CS meat 1 - White pig meat 1} \\
\hline & 1 & 2 & 3 & 4 & 5 & 6 & 7 & 8 & 9 & 10 & 11 & 12 \\
\hline$\%$ & $99 \%-1 \% s$ & $7.5 \%-2.5 \%$ & $95 \%-5 \%$ & $90 \%-10 \%$ & $85 \%-15 \%$ & $80 \%-20 \%$ & $75 \%-25 \%$ & $70 \%-30 \%$ & $65 \%-35 \%$ & $60 \%-40 \%$ & $55 \%-45 \%$ & $50 \%-50 \%$ \\
\hline S0026 & & 95 & 95-102 & $95-102$ & 95-102 & 95-102 & 95-102 & 95-102 & 95-102 & 95-102 & 95-102 & 95-102 \\
\hline S0068* & $250-260$ & $250-260$ & 230-250-260 & $\begin{array}{c}230-250- \\
260\end{array}$ & $\begin{array}{c}\text { 230-250- } \\
260\end{array}$ & $\begin{array}{c}230-250- \\
260\end{array}$ & $\begin{array}{c}230-250- \\
260\end{array}$ & $\begin{array}{c}\text { 230-250- } \\
260\end{array}$ & $\begin{array}{c}\text { 230-250- } \\
260\end{array}$ & $\begin{array}{c}\text { 230-250- } \\
260\end{array}$ & $\begin{array}{c}230-250- \\
260\end{array}$ & $\begin{array}{c}230-250- \\
260\end{array}$ \\
\hline SW1067 & $168-170$ & $168-170$ & $168-170$ & $\begin{array}{c}\text { 160-168- } \\
170\end{array}$ & $\begin{array}{c}\text { 160-168- } \\
170\end{array}$ & $\begin{array}{c}\text { 160-168- } \\
170\end{array}$ & $\begin{array}{c}\text { 160-168- } \\
170\end{array}$ & $\begin{array}{c}\text { 160-168- } \\
170\end{array}$ & $\begin{array}{c}\text { 160-168- } \\
170\end{array}$ & $\begin{array}{c}\text { 160-168- } \\
170\end{array}$ & $\begin{array}{c}\text { 160-168- } \\
170\end{array}$ & $\begin{array}{c}\text { 160-168- } \\
170\end{array}$ \\
\hline SW226 & 178 & 178 & 178 & 178 & $\begin{array}{c}178-180- \\
198\end{array}$ & $\begin{array}{c}178-180- \\
198\end{array}$ & $\begin{array}{c}178-180- \\
198\end{array}$ & $\begin{array}{c}178-180- \\
198\end{array}$ & $\begin{array}{c}178-180- \\
198\end{array}$ & $\begin{array}{c}178-180- \\
198\end{array}$ & $\begin{array}{c}178-180- \\
198\end{array}$ & $\begin{array}{c}178-180- \\
198\end{array}$ \\
\hline \multicolumn{13}{|c|}{$\mathrm{b}$ - CS meat 1 - White pig meat 2} \\
\hline & 13 & 14 & 15 & 16 & 17 & 18 & 19 & 20 & 21 & 22 & 23 & 24 \\
\hline
\end{tabular}

$\% 99 \%-1 \% 97.5 \%-2.5 \%$ 95\% - 5\% 90\% - 10\% 85\% - 15\% $80 \%-20 \% 75 \%-25 \% 70 \%-30 \% 65 \%-35 \% 60 \%-40 \% 55 \%-45 \% 50 \%-50 \%$

\begin{tabular}{|c|c|c|c|c|c|c|c|c|c|c|c|c|}
\hline S0026 & & 95 & 95 & 95 & 95 & 95 & 95 & 95 & 95 & 95 & 95 & 95 \\
\hline S0068 & $250-260$ & $250-260$ & $\begin{array}{c}230-250- \\
260\end{array}$ & $\begin{array}{c}230-250- \\
260\end{array}$ & $\begin{array}{c}230-250- \\
260\end{array}$ & $\begin{array}{c}230-250- \\
260\end{array}$ & $\begin{array}{c}\text { 230-250- } \\
260\end{array}$ & $\begin{array}{c}\text { 230-250- } \\
260\end{array}$ & $\begin{array}{c}230-250- \\
260\end{array}$ & $\begin{array}{c}230-250- \\
260\end{array}$ & $\begin{array}{c}230-250- \\
260\end{array}$ & $\begin{array}{c}230-250- \\
260\end{array}$ \\
\hline SW1067 & $168-170$ & $168-170$ & $\begin{array}{c}\text { 160-168- } \\
170\end{array}$ & $\begin{array}{c}\text { 160-168- } \\
170\end{array}$ & $168-170$ & $\begin{array}{c}\text { 160-168- } \\
170\end{array}$ & $\begin{array}{c}\text { 160-168- } \\
170\end{array}$ & $\begin{array}{c}\text { 160-168- } \\
170\end{array}$ & $\begin{array}{c}\text { 160-168- } \\
170\end{array}$ & $\begin{array}{c}\text { 160-168- } \\
170\end{array}$ & $\begin{array}{c}\text { 160-168- } \\
170\end{array}$ & $\begin{array}{c}\text { 160-168- } \\
170\end{array}$ \\
\hline SW226 & 178 & 178 & $\begin{array}{c}178-192- \\
198\end{array}$ & $\begin{array}{c}178-192- \\
198\end{array}$ & $\begin{array}{c}178-192- \\
198\end{array}$ & $\begin{array}{c}178-192- \\
198\end{array}$ & $\begin{array}{c}178-192- \\
198\end{array}$ & $\begin{array}{c}178-192- \\
198\end{array}$ & $\begin{array}{c}178-192- \\
198\end{array}$ & $\begin{array}{c}178-192- \\
198\end{array}$ & $\begin{array}{c}178-192- \\
198\end{array}$ & $\begin{array}{c}178-192- \\
\mathbf{1 9 8}\end{array}$ \\
\hline
\end{tabular}

analysis. Also, the results show that in the two CS salami is not present meat coming from other pig breeds, different from Cinta Senese, and present in our databank.

\subsection{CS Ham Genotyping}

Ham1 (or Prosciutto1), Pigskin1 (or Cotenna1), Ham2 (or Prosciutto2) were genotyped at the 8 SSRs loci previously listen. The kit used for the DNA extraction was effective also for the DNA extraction from the pigskin, allowing analyzing ham that is undergoing maturation without damage or wastage for producers. The allele sizes characterizing the hams and the pigskin (Table 7) were used to produce a dendrogram of similarity including the six CS meat samples and the different pig breeds belonging to our private databank listed in Table 2 (Figure 3).

The analysis of the dendrogram of similarity reveals that the two CS hams share the genotype typical of the CS pig breed although they don't match none of the six CS pig meat samples suggesting that they belong to different pigs. This was easily predictable for Ham2, which was an aged CS ham not belonging to the butchery batch of the six CS pigs used for the meat analysis. While Ham1, since it doesn't match with anyone of the six CS meat analyzed, it's coming probably from a different CS pig belonging to the butchery batch of the six pigs used for the meat analysis.

Ham1 and Pigskin1 are exactly alike being different parts of the same sample.

\section{Discussion}

Transparency about the origin of animal products is now considered an important component of quality and safety, as perceived by consumers. It represents an important element for the competitiveness and development of local products in the national and international markets as well as for their defense against imitations and counterfeits that could harm the entire production chain. A variety of options are available for pig meat traceability, from the traditional identification method based on ear tags and tattoos, to the electronic identification and 
Table 6. Allele sizes from the CS salami compared to the allele sizes of the six CS meat samples. The analysis reveals a perfect match of the allele sizes in all loci analyzed with the exception of the locus S0068 that shows, in both salami, a 240 bp allele.

\begin{tabular}{ccccccccc}
\hline & CSmeat 1 & CSmeat 2 & CSmeat 3 & CSmeat 4 & CSmeat 5 & CSmeat 6 & Salami 1 & Salami 2 \\
\hline S0026a & 95 & 95 & 95 & 95 & 95 & 102 & 95 & 95 \\
S0026b & 95 & 95 & 95 & 102 & 102 & 102 & 102 & 102 \\
SW240a & 97 & 97 & 93 & 97 & 97 & 97 & 97 & 97 \\
SW240b & 108 & 97 & 97 & 97 & 108 & 108 & 108 & 108 \\
S0068a & 250 & 250 & 250 & 230 & 230 & 230 & $230-240$ & $230-240$ \\
S0068b & 260 & 260 & 260 & 250 & 260 & 250 & $250-260$ & $250-260$ \\
SW122a & 121 & 114 & 121 & 114 & 121 & 114 & 114 & 114 \\
SW122b & 130 & 121 & 130 & 121 & 121 & 121 & $130-121$ & $130-121$ \\
SW632a & 162 & 162 & 162 & 162 & 162 & 169 & 162 & 162 \\
SW632b & 169 & 169 & 162 & 169 & 169 & 169 & 169 & 169 \\
SW1828a & 96 & 96 & 96 & 96 & 96 & 96 & 96 & 96 \\
SW1828b & 100 & 100 & 96 & 96 & 102 & 96 & 102 & 102 \\
SW1067a & 168 & 168 & 168 & 168 & 168 & 168 & 168 & 168 \\
SW1067b & 170 & 168 & 170 & 168 & 168 & 168 & 170 & 170 \\
S0226a & 178 & 178 & 178 & 178 & 178 & 178 & 178 & 178 \\
S0226b & 178 & 178 & 178 & 178 & 178 & 178 & 178 & 178 \\
\hline
\end{tabular}

Table 7. Allele sizes of the CS pigskin and hams. Ham1 and Ham2 show four different alleles which however are recurring alleles in the CS breed genotype.

\begin{tabular}{ccccccccc}
\hline SSR locus & CSmeat 1 & CSmeat 2 & CSmeat 3 & CSmeat 4 & CSmeat 5 & CSmeat 6 & $\begin{array}{c}\text { Ham1 } \\
\text { (or Prosciutto1) }\end{array}$ & $\begin{array}{c}\text { Pigskin1 } \\
\text { (or Cotenna1) }\end{array}$ \\
\hline S0026a & 95 & 95 & 95 & 95 & 95 & 102 & 95 & 95 \\
S0026b & 95 & 95 & 95 & 102 & 102 & 102 & 102 & 102 \\
SW240a & 97 & 97 & 93 & 97 & 97 & 97 & 97 & 97 \\
SW240b & 108 & 97 & 97 & 97 & 108 & 108 & 110 & 110 \\
S0068a & 250 & 250 & 250 & 230 & 230 & 230 & 250 & 250 \\
S0068b & 260 & 260 & 260 & 250 & 260 & 250 & 250 & 250 \\
SW122a & 121 & 114 & 121 & 114 & 121 & 114 & 121 & 121 \\
SW122b & 130 & 121 & 130 & 121 & 121 & 121 & 130 & 130 \\
SW632a & 162 & 162 & 162 & 162 & 162 & 169 & 169 & 169 \\
SW632b & 169 & 169 & 162 & 169 & 169 & 169 & 169 & 169 \\
SW1828a & 96 & 96 & 96 & 96 & 96 & 96 & 98 & 98 \\
SW1828b & 100 & 100 & 96 & 96 & 102 & 96 & 111 & 178 \\
SW1067a & 168 & 168 & 168 & 168 & 168 & 168 & 168 & 178 \\
SW1067b & 170 & 168 & 170 & 168 & 168 & 168 & 170 & 178 \\
S0226a & 178 & 178 & 178 & 178 & 178 & 178 & 178 & 178 \\
S0226b & 178 & 178 & 178 & 178 & 178 & 178 & \\
\hline
\end{tabular}




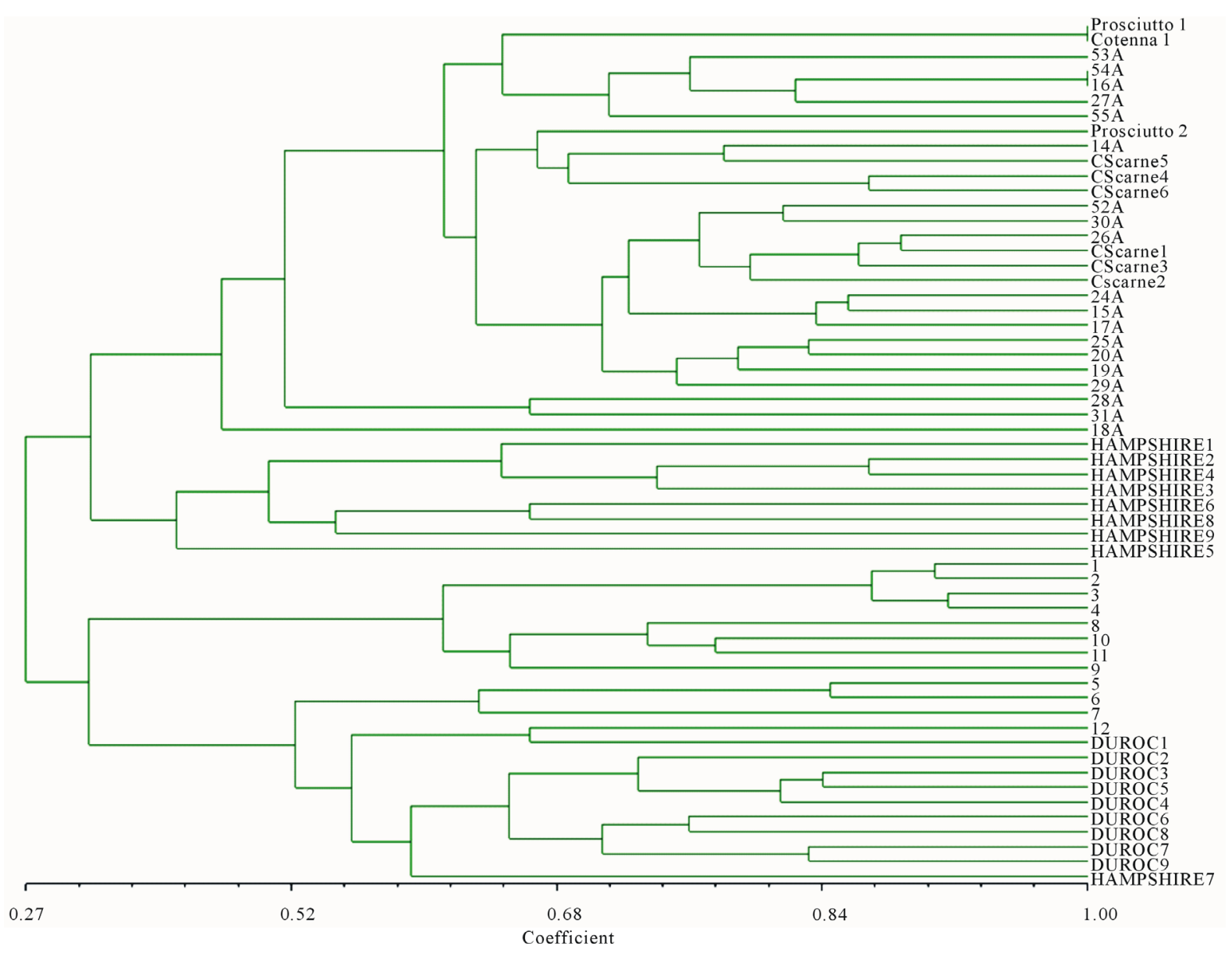

Figure 3. Dendrogram of genetic similarity. The hams analyzed (Prosciutto 1 and Prosciutto 2) show a genotypic profile corresponding to the CS breed detaching from other pig breeds listed in Table 1.

more recently, to DNA analysis. The use of DNA fingerprinting is designed as one of the more advantageous methods to track the product through the entire production chain. Indeed, each animal is genetically unique and the animal's own DNA fingerprinting can be used to track back the origin of pig meat and derived products. In the present study, we developed a molecular traceability method, based on short DNA sequence polymorphisms analysis, to be applied along the production chain of a prestigious Tuscan pig breed, the CS, using a panel of 8 SSRs markers. It has also been shown that the genotyping technique can be used to assess the composition of CS-derived meat products (hams and salami) with a simple PCR-based amplification test.

The genetic characterization of meat from six CS pigs post-mortem has been an essential step for the realization of a complete DNA-based traceability plan, from meat to processed products. The comparison of the genetic profiles of the six meat samples against the available databanks, including the one built-up at the University of Siena [53], proved that the pig analyzed had a CS genotype. Furthermore the availability of autochthonous pig profiles belonging to the CS population, allowed to prove that the salami tested derived from other individuals, than the six taken as CS reference, but still identified as belonging to the CS breed. In fact, within the CS breed more than a fixed true-to-type genotype, there is a range of natural genetic variability that in any case, renders it possible to differentiate the CS population from the main white breeds [53].

In order to validate the method, a detection limit test was conducted in samples obtained by mixing CS and meat derived from unknown white breeds.

According to the data obtained, it was demonstrated that the meat deriving from white breeds was detectable over the CS meat above a 5\% (w/w) threshold detection limit. This qualitative PCR-based approach could be used as a preliminary semi-quantitative method to assess the CS-derived products composition and the degree of purity that is foreseen by the European Union regulation for DOP or PDO (Protected Designation of Origin) 
food products. This test, can be considered as subsidiary to a more accurate, but still to be developed, quantitative DNA testing, based on the use of RT-PCR. Ham is one of the best representatives of the Italian agro-alimentary production. The results method appeared to be particularly suitable for establishing CS ham origin.

The tested hams could be reconducted themselves to specific pigs within the CS population, even if not identical to the six CS references.

The knowledge of the genotypic profile of the CS pig breed is an essential starting point for the development of molecular methods useful to trace the origin of the meats used for the production of typical products.

\section{Conclusion}

Under the food traceability framework, the present work fits with the aim to provide additional techniques of study and analysis that can allow the implementation of a complete genetic traceability plan throughout the CS production chain, from meat to processed products. The opportunity to implement a plan of molecular traceability applied to meat and processed products would ensure not only an increase in the guarantees offered to consumers, but also the possibility for individual companies to differentiate themselves in the market by ensuring the authenticity of the information on the label.

\section{Acknowledgements}

We sincerely thank Prof. Russo and Prof. Davoli (DIPROVAL, Sezione di Allevamenti Zootecnici) for having kindly provided the Duroc and Hampshire genomic DNA. The Farm "Terra di Siena” (Poggibonsi, Siena, Italy) for its collaborative help and for having provided CS meats, CS salami and hams. The present work was financed by the Amministrazione Provinciale of Siena in collaboration with ARA-Toscana (Associazione Regionale Allevatori della Toscana, Italy).

\section{References}

[1] Pugliese, C., Sirtori, F., Acciaioli, A., Bozzi, R., Campodoni, G. and Franci, O. (2013) Quality of Fresh and Seasoned Fat of Cinta Senese Pigs as Affected by Fattening with Cestnut. Meat Science, 93, 92-97. http://dx.doi.org/10.1016/j.meatsci.2012.08.006

[2] Bhatt, T., Buckley, G. and McEntire, J.C. (2013) Proceedings of the August 2011 Traceability Research Summit: This Report Is the Second in a Series on Traceability Summits Sponsored by IFT Beginning in July 2011. Journal of Food Science, S2, B9-B14.

[3] Syntesa, H.L. (2013) Communicating Food Safety, Authenticity and Consumer Choice. Field Experiences. Recent Patents on Food, Nutrition \& Agriculture, 5, 19-34. http://dx.doi.org/10.2174/2212798411305010005

[4] Durán, E., Marín, R.N., Mejías, R.C. and Barroso, C.G. (2009) Traceability of Phytosanitary Products in the Production of a Sherry Wine Vinegar. Journal of Agricultural and Food Chemistry, 57, 2193-2199. http://dx.doi.org/10.1021/jf803729y

[5] Ohtsuki, T., Sato, K., Furusho, N., Kubota, H., Sugimoto, N. and Akiyama, H. (2013) Absolute Quantification of Dehydroacetic Acid in Processed Foods Using Quantitative (1)H NMR. Food Chemistry, 141, 1322-1327. http://dx.doi.org/10.1016/j.foodchem.2013.04.005

[6] Thomas, J.B., Yen, J.H. and Sharpless, K.E. (2013) Characterization of NIST Food-Matrix Standard Reference Materials for Their Vitamin C Content. Analytical and Bioanalytical Chemistry, 405, 4539-4548. http://dx.doi.org/10.1007/s00216-013-6891-4

[7] Narsaiah, K. and Jha, S.N. (2012) Nondestructive Methods for Quality Evaluation of Livestock Products. Journal of Food Science and Technology, 49, 342-348. http://dx.doi.org/10.1007/s13197-011-0286-3

[8] Rogberg-Munoz, A. (2013) Editorial: Technologies in Meat Traceability, Authenticity and Safety. Recent Patents on Food, Nutrition Agriculture, 5, 2. http://dx.doi.org/10.2174/2212798411305010002

[9] Vinci, G., Preti, R., Tieri, A. and Vieri, S. (2013) Authenticity and Quality of Animal Origin Food Investigated by Stable-Isotope Ratio Analysis. Journal of the Science of Food and Agriculture, 93, 439-448. http://dx.doi.org/10.1002/jsfa.5970

[10] Flamini, R. and Panighel, A. (2006) Mass Spectrometry in Grape and Wine Chemistry. Part II: The Consumer Protection. Mass Spectrometry Reviews, 25, 741-774. http://dx.doi.org/10.1002/mas.20087

[11] Perini, M. and Camin, F. (2013) $\delta^{18}$ O of Ethanol in Wine and Spirits for Authentication Purposes. Journal of Food Science, 78, C839-C844. http://dx.doi.org/10.1111/1750-3841.12143 
[12] Aceto, M., Robotti, E., Oddone, M., Baldizzone, M., Bonifacino, G., Bezzo, G., Di Stefano, R., Gosetti, F., Mazzucco, E., Manfredi, M. and Marengo, E. (2013) A Traceability Study on the Moscato Wine Chain. Food Chemistry, 138, 1914-1922. http://dx.doi.org/10.1016/j.foodchem.2012.11.019

[13] Arapitsas, P., Perenzoni, D., Nicolini, G. and Mattivi, F. (2012) Study of Sangiovese Wines Pigment Profile by UHPLC-MS/MS. Journal of Agricultural and Food Chemistry, 60, 10461-10471. http://dx.doi.org/10.1021/jf302617e

[14] Teye, E., Huang, X., Dai, H. and Chen, Q. (2013) Rapid Differentiation of Ghana Cocoa Beans by FT-NIR Spectroscopy Coupled with Multivariate Classification. Spectrochimica Acta Part A: Molecular and Biomolecular Spectroscopy, 114, 183-189. http://dx.doi.org/10.1016/j.saa.2013.05.063

[15] Ritota, M., Casciani, L. and Valentini, M. (2013) PGI Chicory (Cichorium intybus L.) Traceability by Means of HRMAS-NMR Spectroscopy: A Preliminary Study. Journal of the Science of Food and Agriculture, 93, 1665-1672. http://dx.doi.org/10.1002/jsfa.5947

[16] Zhao, H., Guo, B., Wei, Y. and Zhang, B. (2012) Effects of Wheat Origin, Genotype, and Their Interaction on Multielement Fingerprints for Geographical Traceability. Journal of Agricultural and Food Chemistry, 60, 10957-10962. http://dx.doi.org/10.1021/jf3021283

[17] Ritota, M., Casciani, L., Han, B.Z., Cozzolino, S., Leita, L., Sequi, P. and Valentini, M. (2012) Traceability of Italian Garlic (Allium sativum L.) by Means of HRMAS-NMR Spectroscopy and Multivariate Data Analysis. Food Chemistry, 135, 684-693.

[18] Pecetti, L., Tava, A., Romani, M., Cecotti, R. and Mella, M. (2012) Variation in Terpene and Linear-Chain Hydrocarbon Content in Yarrow (Achillea millefolium L.) Germplasm from the Rhaetian Alps, Italy. Chemistry \& Biodiversity, 9, 2282-2294. http://dx.doi.org/10.1002/cbdv.201200072

[19] Dupuy, N., Le Dréau, Y., Ollivier, D., Artaud, J., Pinatel, C. and Kister, J. (2005) Origin of French Virgin Olive Oil Registered Designation of Origins Predicted by Chemometric Analysis of Synchronous Excitation-Emission Fluorescence Spectra. Journal of Agricultural and Food Chemistry, 53, 9361-9368. http://dx.doi.org/10.1021/jf051716m

[20] Tena, N., Lazzez, A., Aparicio-Ruiz, R. and García-González, D.L. (2007) Volatile Compounds Characterizing Tunisian Chemlali and Chétoui Virgin Olive Oils. Journal of Agricultural and Food Chemistry, 55, 7852-7858. http://dx.doi.org/10.1021/jf071030p

[21] Benincasa, C., Lewis, J., Perri, E., Sindona, G. and Tagarelli, A. (2007) Determination of Trace Element in Italian Virgin Olive Oils and Their Characterization According to Geographical Origin by Statistical Analysis. Analytica Chimica Acta, 585, 366-370. http://dx.doi.org/10.1016/j.aca.2006.12.040

[22] Woodcock, T., Downey, G. and O’Donnell, C.P. (2008) Confirmation of Declared Provenance of European Extra Virgin Olive Oil Samples by NIR Spectroscopy. Journal of Agricultural and Food Chemistry, 56, 11520-11525. http://dx.doi.org/10.1021/jf802792d

[23] Bontempo, L., Camin, F., Larcher, R., Nicolini, G., Perini, M. and Rossmann, A. (2009) Coast and Year Effect on H, O and C Stable Isotope Ratios of Tyrrhenian and Adriatic Italian Olive Oils. Rapid Communications in Mass Spectrometry, 23, 1043-1048. http://dx.doi.org/10.1002/rcm.3968

[24] Montealegre, C., Marina, M.L. and García-Ruiz, C. (2010) Separation of Proteins from Olive Oil by CE: An Approximation to the Differentiation of Monovarietal Olive Oils. Electrophoresis, 31, 2218-2225. http://dx.doi.org/10.1002/elps.200900675

[25] Pizarro, C., Rodríguez-Tecedor, S., Pérez-del-Notario, N., Esteban-Díez, I. and González-Sáiz, J.M. (2013) Classification of Spanish Extra Virgin Olive Oils by Data Fusion of Visible Spectroscopic Fingerprints and Chemical Descriptors. Food Chemistry, 138, 915-922. http://dx.doi.org/10.1016/j.foodchem.2012.11.087

[26] Monasterio, R.P., de los Ángeles Fernández, M. and Silva, M.F. (2013) Olive Oil by Capillary Electrophoresis: Characterization and Genuineness. Journal of Agricultural and Food Chemistry, 61, 4477-4496. http://dx.doi.org/10.1021/jf400864q

[27] Rock, L., Rowe, S., Czerwiec, A. and Richmond, H. (2013) Isotopic Analysis of Eggs: Evaluating Sample Collection and Preparation. Food Chemistry, 136, 1551-1556. http://dx.doi.org/10.1016/j.foodchem.2012.03.041

[28] Broeders, S.R., De Keersmaecker, S.C. and Roosens, N.H. (2012) How to Deal with the Upcoming Challenges in GMO Detection in Food and Feed. Journal of Biomedicine and Biotechnology, 2012, Article ID: 402418.

[29] Fernandes, T.J., Oliveira, M.B. and Mafra, I. (2013) Tracing Transgenic Maize as Affected by Breadmaking Process and Raw Material for the Production of a Traditional Maize Bread, Broa. Food Chemistry, 138, 687-692. http://dx.doi.org/10.1016/j.foodchem.2012.10.068

[30] Dong, W., Yang, L.T., Shen, K.L., Kim, B., Kleter, G.A., Marvin, H.J.P., Guo, R., Liang, W.Q. and Zhang, D.B. (2008) GMDD: A Database of GMO Detection Methods. BMC Bioinformatics, 9, 260. http://dx.doi.org/10.1186/1471-2105-9-260

[31] Ganopoulos, I., Sakaridis, I., Argiriou, A., Madesis, P. and Tsaftaris, A. (2013) A Novel Closed-Tube Method Based 
on High Resolution Melting (HRM) Analysis for Authenticity Testing and Quantitative Detection in Greek PDO Feta Cheese. Food Chemistry, 141, 835-840. http://dx.doi.org/10.1016/j.foodchem.2013.02.130

[32] Crandall, P.G., O’Bryan, C.A., Babu, D., Jarvis, N., Davis, M.L., Buser, M., Adam, B., Marcy, J. and Ricke, S.C. (2013) Whole-Chain Traceability, Is It Possible to Trace Your Hamburger to a Particular Steer, a U. S. Perspective. Meat Science, 95, 137-144. http://dx.doi.org/10.1016/j.meatsci.2013.04.022

[33] Liu, X.L., Guo, B., Wei, Y.M., Shi, J.L. and Sun, S.M. (2013) Stable Isotope Analysis of Cattle Tail Hair: A Potential Tool for Verifying the Geographical Origin of Beef. Food Chemistry, 140, 135-140. http://dx.doi.org/10.1016/j.foodchem.2013.02.020

[34] Pegels, N., López-Calleja, I., García, T., Martín, R. and González, I. (2013) Detection of Rabbit and Hare Processed Material in Compound Feeds by TaqMan Real-Time PCR. Food Additives \& Contaminants: Part A, 30, 771-779. http://dx.doi.org/10.1080/19440049.2013.794978

[35] Sakaridis, I., Ganopoulos, I., Argiriou, A. and Tsaftaris, A. (2013) A Fast and Accurate Method for Controlling the Correct Labeling of Products Containing Buffalo Meat Using High Resolution Melting (HRM) Analysis. Meat Science, 94, 84-88. http://dx.doi.org/10.1016/j.meatsci.2012.12.017

[36] Dimauro, C., Cellesi, M., Steri, R., Gaspa, G., Sorbolini, S., Stella, A. and Macciotta, N.P.P. (2013) Use of the Canonical Discriminant Analysis to Select SNP Markers for Bovine Breed Assignment and Traceability Purposes. Animal Genetics, 44, 377-382. http://dx.doi.org/10.1111/age.12021

[37] Nicoloso, L., Crepaldi, P., Mazza, R., Ajmone-Marsan, P. and Negrini, R. (2013) Recent Advance in DNA-Based Traceability and Authentication of Livestock Meat PDO and PGI Products. Recent Patents on Food, Nutrition \& Agriculture, 5, 9-18. http://dx.doi.org/10.2174/2212798411305010004

[38] Yue, G.H., Xia, J.H., Liu, P., Liu, F., Sun, F. and Lin, G. (2012) Tracing Asian Seabass Individuals to Single Fish Farms Using Microsatellites. PLoS ONE, 7, e52721. http://dx.doi.org/10.1371/journal.pone.0052721

[39] Espiñeira, M. and Vieites, J.M. (2012) Rapid Method for Controlling the Correct Labeling of Products Containing Common Octopus (Octopus vulgaris) and Main Substitute Species (Eledone cirrhosa and Dosidicus gigas) by Fast Real-Time PCR. Food Chemistry, 135, 2439-2444. http://dx.doi.org/10.1016/j.foodchem.2012.07.056

[40] Pasqualone, A., Di Rienzo, V., Nasti, R., Blanco, A., Gomes, T. and Montemurro, C. (2013) Traceability of Italian Protected Designation of Origin (PDO) Table Olives by Means of Microsatellite Molecular Markers. Journal of Agricultural and Food Chemistry, 61, 3068-3073. http://dx.doi.org/10.1021/jf400014g

[41] Pafundo, S., Agrimonti, C. and Marmiroli, N. (2005) Traceability of Plant Contribution in Olive Oil by Amplified Fragment Length Polymorphisms. Journal of Agricultural and Food Chemistry, 53, 6995-7002. http://dx.doi.org/10.1021/jf050775x

[42] Pafundo, S., Agrimonti, C., Maestri, E. and Marmiroli, N. (2007) Applicability of SCAR Markers to Food Genomics: Olive Oil Traceability. Journal of Agricultural and Food Chemistry, 55, 6052-6059. http://dx.doi.org/10.1021/jf0701638

[43] Alba, V., Sabetta, W., Blanco, A., Pasqualone, A. and Montemurro, C. (2009) Microsatellite Markers to Identify Specific Alleles in DNA Extracted from Monovarietal Virgin Oils. European Food Research and Technology, 229, 375382. http://dx.doi.org/10.1007/s00217-009-1062-8

[44] Montealegre, C., Marina Alegre, M.L. and García-Ruiz, C. (2010) Traceability Markers to the Botanical Origin in Olive Oils. Journal of Agricultural and Food Chemistry, 58, 28-38. http://dx.doi.org/10.1021/jf902619z

[45] Vietina, M., Agrimonti, C., Marmiroli, M., Bonas, U. and Marmiroli, N. (2011) Applicability of SSR Markers to the Traceability of Monovarietal Olive Oils. Journal of the Science of Food and Agriculture, 91, 1381-1391. http://dx.doi.org/10.1002/jsfa.4317

[46] Bazakos, C., Dulger, A.O., Uncu, A.T., Spaniolas, S., Spano, T. and Kalaitzis, P. (2012) A SNP-Based PCR-RFLP Capillary Electrophoresis Analysis for the Identification of the Varietal Origin of Olive Oils. Food Chemistry, 134, 2411-2418. http://dx.doi.org/10.1016/j.foodchem.2012.04.031

[47] Ganopoulos, I., Bazakos, C., Madesis, P., Kalaitzis, P. and Tsaftaris, A. (2013) Barcode DNA High-Resolution Melting (Bar-HRM) Analysis as a Novel Close-Tubed and Accurate Tool for Olive Oil Forensic Use. Journal of the Science of Food and Agriculture, 93, 2281-2286. http://dx.doi.org/10.1002/jsfa.6040

[48] Rizzello, R., Zampieri, E., Vizzini, A., Autino, A., Cresti, M., Bonfante, P. and Mello, A. (2012) Authentication of Prized White and Black Truffles in Processed Products Using REAL-TIME PCR. Food Research International, 48, 792-797. http://dx.doi.org/10.1016/j.foodres.2012.06.019

[49] Schneider, C., Muller, U., Kilper, R. and Siebertz, B. (2012) Low Copy Number DNA Profiling from Isolated Sperm Using the Aureka ${ }^{\circledR}$-Micromanipulation System. Forensic Science International: Genetics, 6, 461-465.

[50] Fernández, M.E., Goszczynski, D.E., Lirón, J.P., Villegas-Castagnasso, E.E., Carino, M.H., Ripoli, M.V., Rogberg-Muñoz, A., Posik, D.M., Peral-García, P. and Giovambattista, G. (2013) Comparison of the Effectiveness of Mi- 
crosatellites and SNP Panels for Genetic Identification, Traceability and Assessment of Parentage in an Inbred Angus Herd. Genetics and Molecular Biology, 36, 185-191. http://dx.doi.org/10.1590/S1415-47572013000200008

[51] Borrone, J.W., Brown, J.S., Kuhn, D.N., Motamayor, J.C. and Schnell, R.J. (2007) Microsatellite Markers Developed from Theobroma cacao L. Expressed Sequence Tags. Molecular Ecology Notes, 7, 236-239.

http://dx.doi.org/10.1111/j.1471-8286.2006.01561.x

[52] Pinto, L.M., de Oliveira, C.L., dos Santos, L.L., Tarazona-Santos, E. (2014) Molecular Characterization and Population Genetics of Non-CODIS Microsatellites Used for Forensic Applications in Brazilian Populations. Forensic Science International: Genetics, 9, e16-e17. http://dx.doi.org/10.1016/j.fsigen.2013.08.002

[53] Scali, M., Vignani, R., Bigliazzi, J., Paolucci, E., Bernini, A., Spiga, O., Niccolai, N. and Cresti, M. (2012) Genetic Differentiation between Cinta Senese and Commercial Pig Breeds Using Microsatellite. Electronic Journal of Biotechnology, 15, 1-11. http://dx.doi.org/10.2225/vol15-issue2-fulltext-1

[54] Bigliazzi, J., Scali, M., Paolucci, E., Cresti, M. and Vignani, R. (2012) DNA Extracted with Optimized Protocols Can Be Genotyped to Reconstruct the Varietal Composition of Monovarietal Wines. American Journal of Enology and Viticulture, 63, 568-572. http://dx.doi.org/10.5344/ajev.2012.12014 